\title{
THE BREEDING AND DEVELOPMENT OF THE ASCIDIAN PELONAIA CORRUGATA FORBES AND GOODSIR
}

\author{
By R. H. Millar \\ The Marine Station, Millport
}

(Text-figs. I-3)

Pelonaia is a genus of the family Styelidae (subphylum Tunicata; class Ascidiacea) which is very distinct, anatomically, from all other ascidians. It appears, however, to be closer to Styela than to other genera of the family. The only known species, Pelonaia corrugata Forbes \& Goodsir, has a mainly circumpolar arctic distribution and extends for a short distance southward into boreal waters. In British waters it occurs chiefly round the Scottish coast, and is not definitely known south of the Firth of Clyde and Cullercoats. Within its geographical range Pelonaia occurs only locally, being restricted to bottoms of sand or mud. The loose nature of the substratum has had a great influence on the form of the body, which is long, narrow and worm-like. Pelonaia is not attached to a solid object, but instead lives upright in the sand or mud, with the lower part of the body embedded and the upper part, which bears the siphons, projecting freely into the water. The shape and habitat are unlike those of most sand-dwelling ascidians which are usually globular and are often anchored in the surface layer of the sand by filaments of the test.

The development of $P$. corrugata was unknown and was interesting for two reasons: first, the species has a rather isolated position in the family Styelidae, and secondly, the specialized habitat of the adult might be expected to affect the method of development.

\section{Material AND METHODS}

Specimens were dredged from sandy mud at depths of $40-47 \mathrm{~m}$, off Fairlie in the Firth of Clyde. Fertilized eggs were obtained in two ways: (I) by allowing animals kept in aquarium tanks to liberate eggs and sperm spontaneously, the eggs being removed to Petri dishes after fertilization; and (2) by taking eggs and sperm from the ducts of animals within a few hours of collection, and adding sperm from one individual to eggs from another. Developing eggs were kept in covered Petri dishes or watch-glasses containing freshly collected unfiltered sea water. The water, which was changed once daily, maintained a temperature of $8.0-10 \cdot 0^{\circ} \mathrm{C}$. A few embryos were fixed in Boveri's picroacetic mixture, embedded in paraffin wax (m.p. $49^{\circ} \mathrm{C}$.), and sectioned at $8 \mu$. 


\section{OBSERVATIONS}

\section{The Breeding Season}

Specimens were collected at about monthly intervals between August I950 and February I954. In most samples the population could be separated by inspection into two groups representing different age classes. There therefore appeared to be a limited breeding season. Fig. I shows the distribution by body volume of the specimens taken on II January I954. Animals up to about $\mathrm{I} \cdot 0 \mathrm{ml}$. were about I year old and those between $\mathrm{I} \cdot 2$ and $2.4 \mathrm{ml}$. about 2 years old. Only the animals in the older group had fully developed and functional

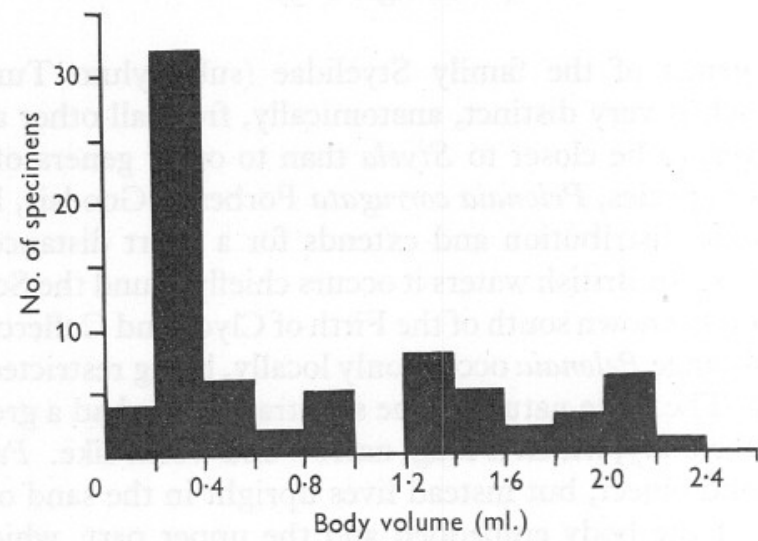

Fig. I. Distribution by body volume of the specimens of $P$. corrugata collected on II Jan I954

gonads at this time of year. The breeding season was found by examining the specimens in the monthly samples, and noting when the gonads started to empty and when they had completely emptied. In 1952 spawning had not yet started on 17 January, but was completed before 25 March. In I953 spawning had just started on I2 January, and was finished by 26 January. In I954 spawning started between I5 January and 22 January and ended about I5 February. The breeding season in this area is therefore confined to a period of 2-4 weeks in January or February. During breeding in 1954 the bottom temperature over the spawning animals was about $7.5^{\circ} \mathrm{C}$., and animals kept in an aquarium tank spawned at a temperature of about $7.0^{\circ} \mathrm{C}$. Thus $P$. corrugata breeds, in the Firth of Clyde, when the sea is almost at its coldest, a fact correlated with the mainly arctic distribution of the species. The southern limit of its world distribution coincides roughly with the February isotherm of $7 \cdot 2^{\circ}$ C. (Fig. 2 ); higher temperatures further south probably limit distribution by preventing breeding.

The ripe ovum (Fig. 3A) is spherical, bright orange in colour, and from 270 to $280 \mu$ in diameter. It is surrounded by a thin chorion forming a spherical transparent shell 300 to $320 \mu$ in diameter. The outer follicle cells, which are 
rounded and have no vacuoles, cover the chorion. Inner follicle cells are inconspicuous. Much yolk is present and the egg has a high specific gravity. Consequently the eggs of Pelonaia drop to the bottom when shed into the

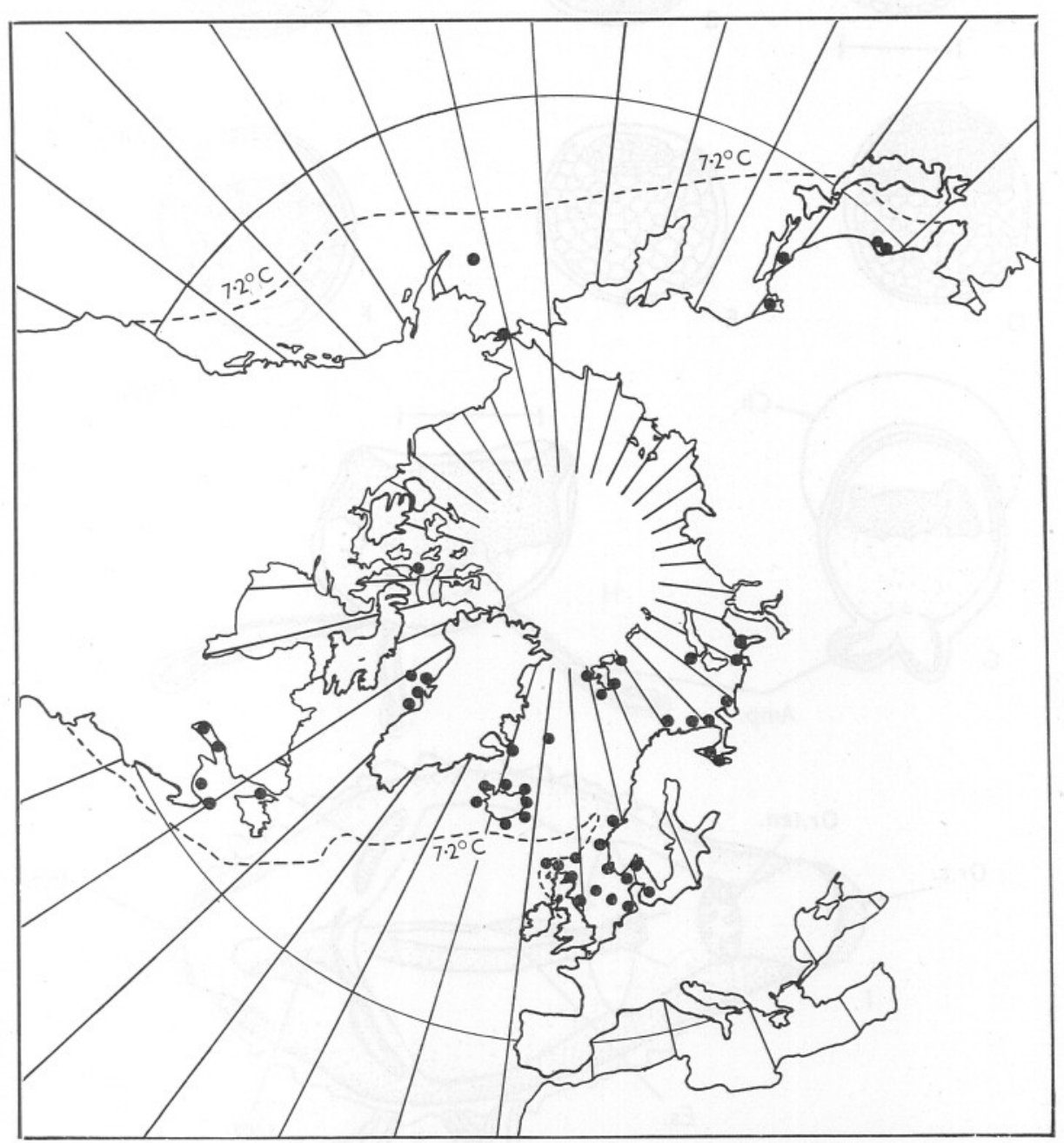

Fig. 2. Known geographical distribution of $P$. corrugata, showing also the February isotherm of $7 \cdot 2^{\circ} \mathrm{C}$.

water, instead of remaining suspended as do the eggs of many ascidians. This is important in connexion with the mode of development, as will be seen later.

The sperm has the shape common in ascidians. The narrow rod-like head about I $2 \mu$ long has, near one end, an asymmetrical protoplasmic bulge, and arising from this end, a tail about $62 \mu$ long. 

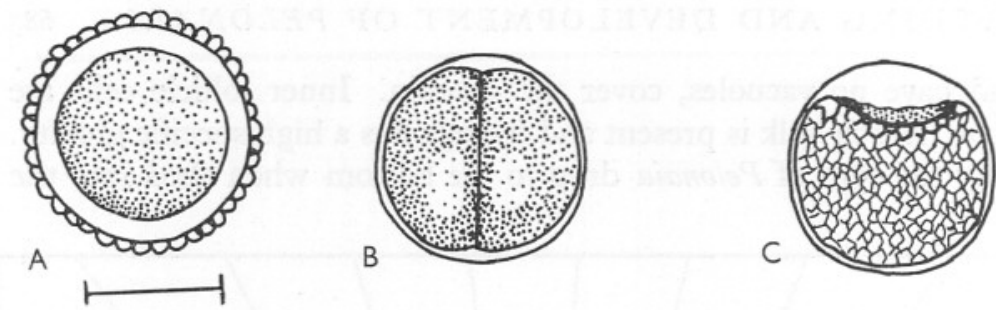

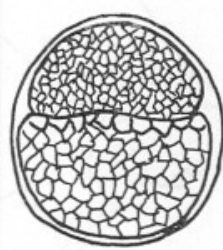

D

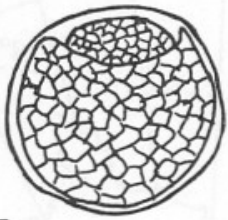

E
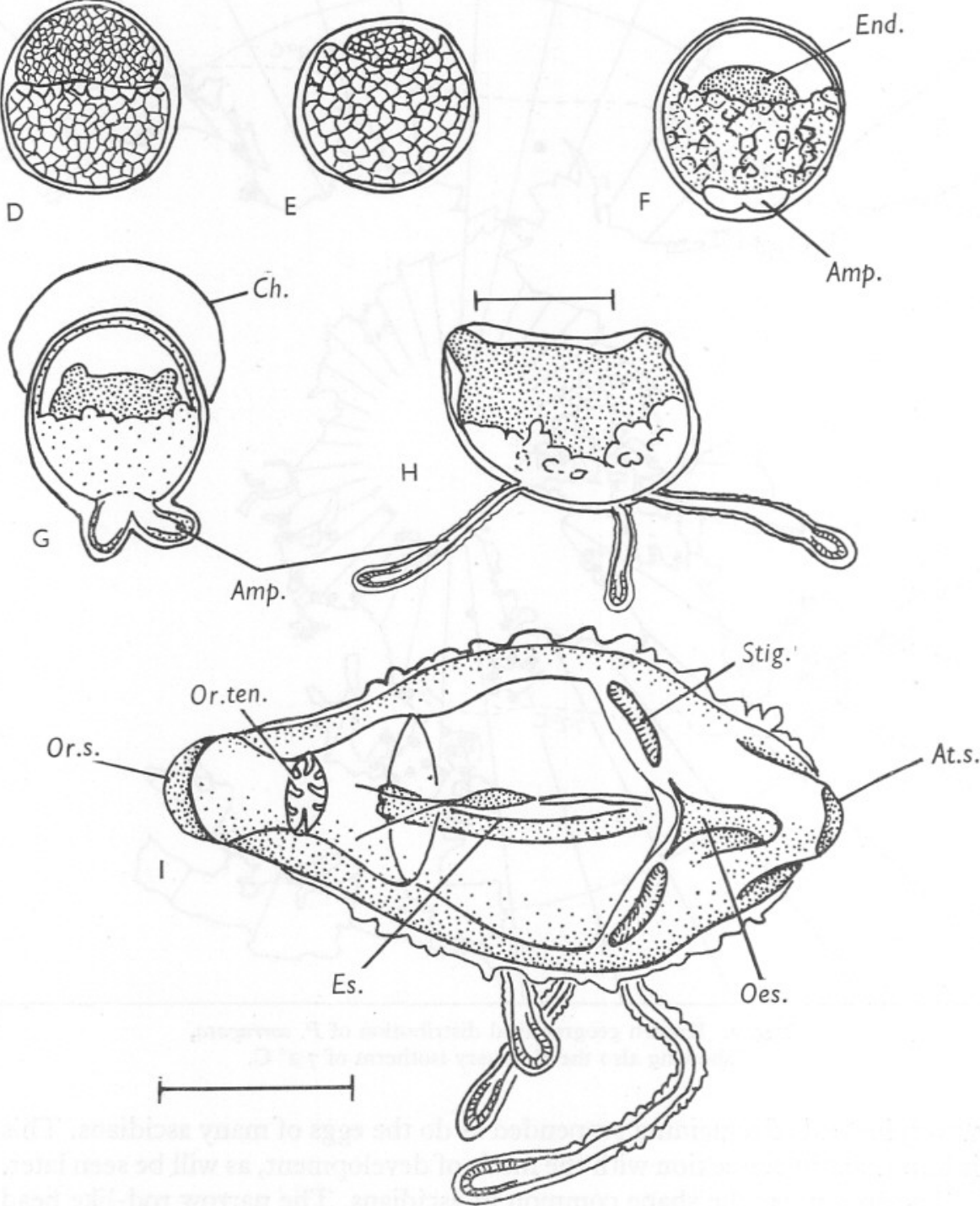

Fig. 3. Development of $P$. corrugata. A, unfertilized egg; B, two-cell stage, showing area of pale protoplasm in each cell; C, gastrula; D, two-hemisphere stage, the lower hemisphere consisting of large pale cells and the upper one of small dark cells; $\mathrm{E}$, later two-hemisphere stage; F, embryo showing rudiments of two ampullae; G, rupture of chorion; H, embryo after attachment; $\mathrm{I}$, young ascidian. D-H are lateral views and I a dorsal view. In $\mathrm{B}-\mathrm{G}$ the outer follicle cells have been omitted. The scales represent $200 \mu$. Amp., ampullae; At.s., atrial siphon; Ch., chorion; End., endoderm; Es., endostyle; Oes., oesophagus; Or.s., oral siphon; Or.ten., oral tentacles; Stig., stigma. 


\section{Embryonic Development}

Artificial fertilization was attempted each month for over 2 years, but succeeded only in January 1953 and January and February 1954. At other times the sperm was almost completely inactive. Only a few, and usually less than I2, of the eggs taken from any animal became fertilized. There were therefore not enough embryos to allow fixation and sectioning of all the most important stages, and the following outline of development was obtained mainly from the study of live embryos.

Cleavage of the fertilized egg is symmetrical and is like that of other ascidians up to the time of gastrulation. The gastrula (Fig. $3 \mathrm{C}$ ) is formed within about $\mathrm{I} 2 \mathrm{hr}$. of fertilization at a temperature of $8 \cdot 0-10 \cdot 0^{\circ} \mathrm{C}$. There is little localization of coloured protoplasm into presumptive areas, such as occurs in some styelid ascidians and occasionally amongst other families. In the 2- and 4-cell stages, however, each cell shows a pale area in the otherwise uniformly coloured protoplasm (Fig. 3B), and in the I6-cell stage there is a group of four dark cells. Later stages show no colour pattern. Following gastrulation the embryo rounds off and remains spherical for about a day. During the next 2 days the spherical stage is transformed into a two-hemisphere stage (Fig. 3D). In this, one half of the embryo consists of large pale orange cells and the other half of small dark orange cells. The hemisphere of large cells now slowly grows and begins to envelop the other hemisphere, which meanwhile shrinks (Fig. 3E). At the end of the process, usually 4-6 days after gastrulation is complete, the embryo has an internal ovoid mass of small dark cells surrounded by a sphere, part of which is still recognizable as the large pale cells of earlier stages. The internal dark mass is endoderm and the surrounding sphere ectoderm. The ectoderm at one point now differentiates and by rapid growth forms a pair of blister-like swellings, which are the rudiments of two ampullae (Fig. 3F). The whole development so far has taken place within the chorion, which however is now ruptured by the elongation of the ampullae and by the swelling due to the secretion of test over the whole ectoderm (Fig. $3 \mathrm{G}$ ). The ampullae grow rapidly, and by secreting sticky test substance, fix the embryo to the substratum. The swollen ends of the ampullae have tall epidermal cells and are regions especially active in the secretion of test. In the culture vessels the embryos became attached to the glass by means of the ampullae, but in nature they would presumably be fixed to sand grains by the same mechanism. At this point in development the central endodermal mass shows the rudiments of the two siphons projecting outwards towards the enclosing ectoderm. The remaining central mass is the rudiment of the pharynx and gut. The orientation of the future ascidian can now be established: the ampullae arise from the ventral surface and the siphons mark the dorsal surface. In most specimens a third ampulla appears at this stage (Fig. $3 \mathrm{H}$ ), but in some only two are present throughout development. The siphons are now completed by fusion of the 
endodermal rudiments with the ectoderm, which also enters into their formation. The endostyle and dorsal lamina appear in the pharynx, and the oesophagus and other parts of the gut become visible. Branchial stigmata are not formed until some time later; in one individual the first pair appeared on the 2oth day after fertilization, but in others not until the 4oth day. The young ascidian (Fig. 3 I) now has its essential organization and is soon able to feed.

\section{Discussion}

A few attempts have been made to relate the geographical distribution of ascidians with sea temperatures (Hartmeyer, I923-24; Thompson, I930-34; D. \& A. Carlisle, 1954) but very little is known of the exact way in which temperature limits the range. We do not know in any particular species, for instance, whether high summer temperature or low winter temperature is a limiting factor, and whether the boundaries of distribution are fixed by inability of the adult to survive, or to breed successfully, beyond the temperature limits. In Pelonaia it appears that the southern boundary is fixed by the failure of breeding in higher winter temperatures farther south. It would be interesting to know the breeding period in northern waters, and we would expect it to be shifted progressively towards the summer in the more northerly parts of the range. Although the limiting factor at the northern boundary of the range is unknown, it may well be a winter temperature too low for survival of the adult. If this is so Pelonaia illustrates the type 4 geographical zonation, as defined by Hutchins (1947); in this type of distribution both the poleward and the equatorward limits are set by the winter temperature.

The distribution of the species is further limited by the need of a substratum loose enough to allow the adult to be partially embedded, but not subject to shifting with the consequent danger of burial. Such a habitat, however, is local, and the species may require for survival not the wide dispersal of larvae but rather their retention in the area already inhabited by the adults. The pelagic larval stage which is normal in other styelids and indeed in most ascidians, has been eliminated in Pelonaia. Moreover, the egg is heavy, and probably sinks to the bottom instead of drifting in water currents. The young stages therefore develop and are established close to the breeding parent stock. In the elimination of a pelagic larval-stage Pelonaia presents a striking parallel with the sand-dwelling species of the Molgulidae. Berrill (I93I) has shown that in this family the sand-flat habitat is common and is usually accompanied by anural development. He regards the suppression of the larval stage as correlated with the habitat although he does not consider 'that such a habitat is directly responsible for its origin, but that conceivably through a lessening of the rigour of natural selection, those species in which it does arise are allowed to survive, whereas among attached shore forms they are not'. But the occurrence of anural development in the genus Pelonaia, which although unrelated 
occupies a similar habitat, suggests that this type of development is of positive survival value.

In this investigation I have not been able to make a detailed study of the embryology, but intend to do so in the future, as several very interesting problems are involved. First, there is the fate of the tissues which in urodele forms produce the tail. Secondly, the larval sense organs (ocellus and otolith) fail to develop, but we do not know whether the larval nervous system is totally suppressed, and if so, how the adult system arises. Thirdly, the stages intermediate between the gastrula and the hatching embryo are obscure, particularly the two-hemisphere stage which requires an explanation in terms of cell-lineage. Fourthly, what is the relation between those changes leading to the formation of the young ascidian stage and the changes which occur in the metamorphosing larva of urodele species?

I wish to thank the skipper and crew of M.F.V. Calanus for their help in collecting material, and my wife for her care of the cultures.

\section{SUMMARY}

Pelonaia corrugata in the Firth of Clyde breeds for only 2-4 weeks in January or February. The species is oviparous. Early cleavage is similar to that of other ascidians, but after gastrulation the embryo passes through a twohemisphere stage. One of these hemispheres is endodermal. From the other hemisphere, which slowly envelops the endoderm, two ampullae grow and fix the embryo to the substratum. The young ascidian develops directly from this attached embryo, and the development is therefore anural. Elimination of the pelagic larval stage is regarded as an adaptation to the sand-dwelling habit of the adult, as it prevents dispersal to unsuitable habitats.

\section{REFERENCES}

Berrill, N. J., I93I. Studies in tunicate development. Part 2. Abbreviation of development in the Molgulidae. Phil. Trans., B, Vol. 219, pp. 281-346.

Carlisle, D. B. \& Carlisle, A. I., I954. Notes on the Didemnidae (Ascidiacea). I. The presence of Didemnum (Leptoclinides) faeröense (Bjerkan) in the Plymouth area. F. Mar. biol. Ass. U.K., Vol. 33, pp. $2 \mathrm{I}-5$.

HartmeYer, R., I923-24. Ascidiacea. Dan. Ingolf-Exped., Vol. 2, pt. 6, 368 pp.; pt. 7,278 pp.

Hutchins, L. W., I947. The bases for temperature zonation in geographical distribution. In Symposium on marine ecology. Ecol. Monogr., Vol. I7, pp. 325-35.

Thompson, H., I930-34. The Tunicata of the Scottish area. Parts I-III. Sci. Invest. Fish. Bd Scot., I930, No. 3, 45 pp.; I931, No. I, 46 pp.; 1932, No. 2, 42 pp.; I934, No. I, 44 pp. 